JELTL (Journal of English Language Teaching and Linguistics) e-ISSN: 2502-6062, p-ISSN: 2503-1848

2019, Vol. 4(2)

www.jeltl.org

\title{
Graphic Organizer as Strategy to Teach Extensive Reading on Non-Fiction for EFL Learners
}

\author{
Astried Damayanti \\ STKIP PGRI Trenggalek, Indonesia \\ e-mail: astried.damayanti@yahoo.co.id
}

\begin{abstract}
The research was conducted based on the teaching and learning Extensive Reading on Nonfiction for second semester students of English Language Education Department of STKIP PGRI Trenggalek. The research was aimed to apply graphic organizer appropriate with the type of non-fiction passage. The graphic organizers utilized in the research were Keep-inTime Sequence String for Chronological Order passage, Venn Diagram for Compare and Contrast passage and Character Traits for Description passage. The research was also intended to know the students' comprehension of the passage after the utilization of graphic organizer and their response toward the use of graphic organizer in learning extensive reading. The students' comprehension was evaluated by summarization. They were assigned to summarize each passage based on the graphic organized arranged in previous activity. Meanwhile, attitude scale was used to know the students' response during the utilization of graphic organizer in learning extensive reading. The score of the summarization revealed that the students' reading comprehension was good. The mean of their summarization was 81.67. Based on the result of attitude scale, the students gave good response toward the utilization of graphic organizer in learning extensive reading.
\end{abstract}

Keywords: Extensive Reading, Graphic Organizer, Non-fiction

\section{INTRODUCTION}

Learning reading is one crucial activity for EFL learners. Harmer (2007) describes English as a Foreign Language (EFL) as the situations and students were studying English and using it with other English speakers in the world - when the students might be tourists or business people. Meanwhile, Greenall and Pye (1991) argue that learning reading in the mother tongue is different with it in the foreign language. In the mother tongue, learning 


\section{Astried Damayanti}

reading is enjoyable activity but it seems highly desirable to reproduce the enjoyment if reading is started in the foreign language. The motivation of learning reading in the mother tongue and foreign language is different also. The learners in the mother tongue possess reason for reading and the motivation to do it because of their self-directed. They can choose the passage they want to read. But on the contrary, the learners in foreign language are controlled and handled by the teacher because learning reading is classroom activity. The teacher often tells implicitly or explicitly what the learners have to read and how to read it. Damayanti (2018) states that motivation can be stimulated though text and content. It indicates that the teacher should stimulate the learner's motivation in learning reading. Further, Harmer (2007) explains that attitude of people can affect and influence the student's motivation to the task in learning English. It means that the people form environment where the students involves the learning process. Basuki et al (2018) add that suitable materials as souce in learning is very important to be prepared by the teacher to support the learning process In conclusion, the teacher has a big role to motivate and stimulate the students who engages in learning process.

One strategy can be applied in teaching reading is using graphic organizer. The utilization of graphic organizer in learning reading had been applied by some researchers. Manoli and Papadopoulou (2012) had conducted a research about graphic organizers applied as one of reading strategis. The research was aimed at finding the evidence from the effectiveness of graphic organizers in learning text. Similarly, Heidarifard (2014) carried out the research about the effect of graphic organizer on learning reading comprehension. Experimental design was conducted in this research. The conclusion shows that the utilization of graphic organizer gives good effect in learning reading comprehension. The learners give positive response and feel more confidence during graphic organizer applied in learning reading comprehension. Further, Olzak (2014) investigated the utilization of graphic and semantic organizers as one of cognitive strategies and instructions in reading. The finding of the research shows that graphic and semantic organizers are successfully utilized by the students in reading activity. The use of graphic organizer also was implemented by Sam and Rajan (2013). They intended to enhance the skill of reading comprehension for middle school of ESL students. The utilization of graphic organizer motivated the students' creativity to comprehend the passage they read.

Based on the explanation above, the researcher is interested in applying graphic organizer in reading class. She conducts the research based on teaching and learning Extensive Reading of Non-fiction which is taken by the second semester students of English Language Education Department of STKIP PGRI Trenggalek in 2018/2019 academic year. This research is aimed to implement graphic organizer to teach Extensive Reading on Nonfiction.

In the research, the researcher is interested in finding: (1) the students' response on graphic organizers applied, (2) the students' result of reading comprehension after graphic organizers applied. The result of students' reading comprehension is evaluated by summarization task based on graphic organizers created. 


\section{LITERATURE REVIEW}

According to Tiryaki and Tutunis (2012), extensive reading can improve the mount of vocabulary the leaners have. Further, Aliponga (2007) adds that extensive reading provides large quantities from materials. Stoller (as cited in Yulia, 2018) also explains that extensive reading is approach in teaching and learning reading with large quantities of materials which are enjoyable, interesting and understood without great effort. It can be concluded that extensive reading is a reading activity with large quantities materials for enjoyment. Therefore, Brown (2007) explains that reading for enjoyment and reading without finding the unknown words were highly correlated with all language competences or skills. It means that extensive reading involves language proficiency. Harmer (2007) explains that in extensive reading, it is not enough to ask students to 'read a lot', but it is very crucial to offer them a different program with suitable materials, facilities, assignment and good guidance. He adds that one of the fundamental conditions of a successful extensive reading program is that the students should be reading materials which they can understand. Most of students will not practice a lot of extensive reading unless their teacher encourages them. In short, the teacher should choose the appropriate way to teach extensive reading.

Mar et al (2006) define non-fiction as typically intended to describe or something in nature, meanwhile fiction takes a narrative form. Further, Bearne (2002) explains that nonfiction can build student's understanding of the content with some processes of activities; they are hypothesizing activity, questioning activity, exploring activity, reflecting activity, explaining activity, describing activity, persuading activity and evaluating activity. It means that non-fiction can assist students to think systematically and greatly about what happens in the world. According to Wray and Lewis (1997), the followings are six texts forms in nonfiction: (1) recount text (to retell events), (2) report text (to present factual information), (3) procedure text (to present some steps of instruction to do something), (4) explanation text (to show or explain how something works), (5) persuasive text (to present argument to influence the reader), (6) discussion text (to present information from different poin a view to reach conclusion with the evidence provided. From the six texts, there are some patterns that the students can model. They are: (1) chronological order (events that presented in time sequence), (2) compare and contrast (presenting similarities and differences), (3) concept/definition (information about a group of person, events, places or things with their characteristics), (4) description (attributes of specific persons, events, places or things), (5) episode (information about specific people, specific duration, specific events or incidents), (6) generalization/principle (information of general statements with examples provided), (7) process/cause and effect (information with steps to specific outcome). In this research, the researcher applies graphic organizer for chronological order, compare and contrast, and description passage. She uses the suitable graphic organizer applied for those texts.

This research is conducted to motivate students in learning reading though graphic organizer suitable with the materials (non-fiction materials). According Brown (2007), reading a long text of ideas or event can be extremely overwhelmed. He adds that semantic mapping or grouping several ideas into clusters can help the readers overcome it. Olszak (2014) defines graphic and semantic organizer as visual ways to create and show the ideas from text. It can be formed as tables, diagram, organizers or webs. They greatly assist the students to comprehend the text in focusing the concept and the way how to connect to other 


\section{Astried Damayanti}

concepts. Olszak adds that some benefits can be provided by applying graphic organizer in learning reading; they are: (1) helping the students to differentiate between fiction and non fiction, (2) assisting students to show relationship of the text, (3) guiding the students to summarize well. It means that graphic organizer also helps the students with difficult of new words they find in the text or passage. Basuki et al (2018) argue that vocabulary is very crucial as the central in complexity of language and as the first step for those who want to learn new or different language. In short, graphic organizer can help, assist and guide the students in reading activity.

Sam and Rajan (2013) define graphic organizer as diagram to represent the directed relationship from sequence of boxes that are connected with some arrows to show the events. Some functions can be provided by graphic organizer; they are: (1) clarifying information and organizing it into main idea, supporting details, fact, opinion, etc), (2) organizing some information into a paragraph, (3) constructing meaning from difficult words, (4) understanding the context with prior knowledge, (5) identifying the errors of conceptual and perceptual occur in reading passage. To conclude, graphic organizer assists learners to get the important information of a passage.

\section{RESEARCH METHODS}

The design used in the research is qualitative research. According to Ary et al (2002) qualitative researchers search to understand of a phenomenon with focusing to the whole of the picture rather than breaking it down into two or some variables Qualitative research is intended to present the whole picture and depth of understanding, rather than a numeric analysis data. Case study is carried out in the research. Further, Ary et al (2002) define case study as a depth study of a unit, for example one individual, one group, one program etc. It is intended to obtain a detailed description and perceiving the entity. This research is conducted to implement graphic organizer in learning extensive reading with different passage of nonfiction. The researcher applies graphic organizer and investigates the students' reading comprehension after the implementation.

\subsection{Subjects of the Research}

The subjects of the research are the second semester students of English Language Education Department of STKIP PGRI Trenggalek in 2018/2019 academic year, consisting of 27 students. The research is conducted based on Extensive Reading on Non-fiction subject. The researcher applies graphic organizers for non-fiction materials. Graphic organizers are utilized in chronological order, compare and contrast, and description passage. The researcher employs the suitable graphic organizers tor those passages. The graphic organizers used are presented as follows.

\subsubsection{Chronological Order}

Robb (2003) defines chronological order as the arrangement some details or time order or the events arranged in order based on what really happen. For chronological order, the researcher uses Keep-in-Time Sequence String. It presents the sequence of important events. It is used to write the chronological order of special moment. Keep-in-Time Sequence String 
is displayed with several circles to present the order of the event. The cycles are connected each other to show that the events are related.

\subsubsection{Compare and contrast}

Compare and contrast shows the similarities and differences between two things or more. Venn diagram is employed to show the similarities and differences of the things. The Venn diagram consists of two or more circles to present the similarities and the differences of them. The points inside both circles presents their similarities. On the other hand, the differences are displayed in each cycle. It means that the points outside of the curve from both circle present the characteristic of each thing compared.

\subsubsection{Description}

This passage provides information about attributes of specific persons, events, places or things. Graphic organizer used for this passage is Character Traits. It displays the characteristics or traits of thing being described. A box is provided to write the characteristics or traits the thing has. Before completing the box, the thing such as object, person or place is written to show what is being described in the passage.

The utilization of graphic organizer in Extensive Reading on Non-Fiction class are conducted in several steps. The class always begins with the explanation of non-fiction materials (chronological order, compare and contrast, and description). The researcher then delivers the passage of non-fiction materials.. The passages in several meetings are different. The researcher delivers non-fiction materials with passage of chronological order, compare and contrast, and description. Then she assigns the students to practice reading the passage carefully. She gives some questions as brainstorming to motivate the students and get involved with the topic in passage. Next activity is explaining the graphic organizer. She explains Keep-in-Time Sequence String for chronological order, Venn Diagram for compare and contrast, and Character Traits for Description. After teaching about graphic organizer, she instructs the students to create graphic organizer for writing the important information based on the passage. She asks the students to read again and analyze the passage to find the words, phrases or statement written in their graphic organizer. She guides the students to make their graphic organizer. After all students finish with their graphic organizer, she assigns the students to make a summary from the graphic organizer created. Making summary had been explained in the previous semester. She reviews and reminds some strategies how to summarize well. Then she asks them to submit their summary with the graphic organizer attached to be evaluated.

\subsection{Instruments}

The researcher uses some research instruments to carry out the research, namely observation, test and attitude scale. Ary et al (2002) state that observation is the basic method for gaining data in qualitative research. In this research, the researcher is assisted by her partner to observe the behaviour and activities of the subjects during graphic organizer applied in reading class. Observation checklist is constructed to help her during the implementation of graphics organizer in reading class. Test is carried out to evaluate the students' reading comprehension. Summarization is employed as the reading test. According 


\section{Astried Damayanti}

to Chiu (2015), summarizing is one of combination between reading for academic purposes and writing activities. In this research, the researcher assigns the students to make a summary from the graphic organizer created suitable with the passage delivered. She uses scoring rubric for summarization test adapted from Chiu (2015). The scoring rubric covers: (1) Thesis statement, which is related to the clear topic and main idea stated; (2) Content Inclusion \& Exclusion, which evaluates about major details arranged in good order and no unimportant information or details are stated; (3) Sentence Transformation, which evaluates if the author restates the ideas with his/her own words; (4) Grammar \& Mechanic, which is related to the use of mechanics, usage, grammar, spelling.

From the result of summarization, the researcher evaluates the students' comprehension of the passage delivered. McNeil (1992) argues that summarizing is crucial for understanding. Further, he adds some strategies to summarize; they are: (1) eliminating unnecessary information, (2) eliminating important information or material but redundant. Attitude scale is used to measure the degree to which an individual exhibits the characteristic of interest (Ary et al, 2002). Likert Scale is used in the research. Ary at al (2002) explain that A Likert Scale evaluates attitudes toward a topic by providing a set of statements of the topic and asking respondents to show for each whether they strongly agree, agree, are undecided, disagree, or strongly disagree. In this research, the researcher measures the students' attitude toward the utilization of graphic organizer in reading class. She constructs ten statements and provides multiple responses toward the use of graphic organizer in learning extensive reading for non-fiction materials.

\subsection{Data Analysis}

The data obtained will be analyzed with several steps. Firstly, the data from observation is analyzed to show whether all activities to apply graphic organizer done by the researcher and the students. It will indicate if graphic organizer is implemented well. Secondly, the researcher analyzes the students' score of summarization from the graphic organizer made. She calculates the mean of students' score of each summary from chronological order passage, compare and contrast passage, and description passage. Then she calculates the mean, median and modus of the whole students' score. The attitude scale is analyzed by applying Likert Scale; where the researcher provides five multiple responses (strongly agree, agree, undecided, disagree and strongly disagree) with score of each response is 5, 4, 3, 2 and 1 . Then she calculates the score of each statement and makes conclusion of the result.

\section{FINDINGS}

This findings of the research cover the result of observation, test and attitude scale during the graphic organizer applied in Extensive Reading on Non-fiction subject.

\subsection{The Result of Observation}

The observation was conducted to observe the behaviour and activities of the researcher and the students during graphic organizer applied in extensive reading class. The researcher used different observation checklist for different non fiction materials. She 
provided observation checklist for chronological order, compare and contrast, and description passage. The researcher was assisted by her partner to observe while graphic organizer was applying in extensive reading class. Her partner observed and completed the observation checklist provided. The observation checklist consisted of 22 statements about activities done by the researcher and the students with two options, "Yes" and "No". For chronological order material, the observation was conducted on Tuesday, March 5, 2019 The researcher was assisted by her partner who used observation checklist to guide her. The class observed was the second semester students of English Language Education Department of STKIP PGRI Trenggalek who joined Extensive Reading on Non-Fiction subject; consisting of 27 students. The result shows that the researcher implemented the utilization of graphic organization well. She started with explanation of chronological order with its passage. Then she guided the students to create Keep-in-Time Sequence String as appropriate graphic organizer for chronological order passage. With their Keep-in-Time Sequence String, they were instructed to make a summary. The researcher assisted and guided them to finish it. They submitted their summary with their Keep-in-Time Sequence attached.

The researcher continued with compare and contrast as one of non-fiction material. The observation was done on Tuesday, March 26, 2019. Her partner assisted her to observe activities during the graphic organizer applied. The second semester students of English Language Education Department of STKIP PGRI Trenggalek who joined Extensive Reading on Non-Fiction subject were observed; 27 students attended the class. The result of observation shows that graphic organization was applied well. The class was started with the explanation of compare and contrast with its passage. The researcher then assisted the students to create Venn Diagram as suitable graphic organizer for compare and contrast based on the passage delivered. After creating it, they were assigned to summarize and submitted it with their Venn Diagram.

The class continued with description material. The observation was conducted on Tuesday, April 16, 2019. It was done to observe the same class, the second semester students of English Language Education Department of STKIP PGRI Trenggalek who joined Extensive Reading on Non-Fiction subject with 27 students. The result also shows that the researcher utilized the graphic organizer well. She began with explanation of description and its passage as example. She then continued with Character Traits as graphic organizer for description. She asked the students to make Character Traits based on the passage delivered. She guided and assisted the students to create it. With their Character Traits, the students were assigned to summarize and submit it as final work.

From the result of observation done, it concludes that the researcher applied graphic organizer well based on the activities constructed in observation checklist.

\subsection{The Result of Test}

The test was conducted to evaluate the students' reading comprehension of non-fiction. Summarization was used as the reading test. The researcher assigned the students to make a summary of each passage distributed based on graphic organizer made in the previous activity. The summaries consist of chronological order summary, compare and contrast summary and description summary. The summarization evaluation was done based on scoring rubric of summarization test adapted from Chiu (2015). The evaluation covered 


\section{Astried Damayanti}

Thesis Statement, Content Inclusion \& Exclusion, Sentence Transformation, Grammar and Mechanics. The score covered the chronological order summary, compare and contrast summary and description summary.

The researcher then calculated the mean, median and modus of summarization score. From the result of calculation, the mean of students' score was 81.67. Meanwhile, the median was 80 and the modus was 80 .

\subsection{Attitude Scale}

Attitude scale was used to know the students' responses after the graphic organizer applied in reading learning. The researcher constructed ten statements about the utilization of graphic organizer. She provided five multiple responses, namely strongly agree (SA), agree (A), undecided (U), disagree (D), strongly disagree (SD). Strongly agree would receive a weight of 5, agree would receive of 4 , undecided would receive a 3 , disagree would receive a 2 and strongly disagree would receive a 1 . The attitude scale was distributed to 27 students as respondents. The result of attitude scale is presented as follows.

Table 1. The Attitude Scale toward the Utilization of Graphic Organizer

\begin{tabular}{|c|c|c|c|c|c|c|c|}
\hline No. & Statement & $\mathbf{S A}$ & $\mathbf{A}$ & $\mathbf{U}$ & $\mathbf{D}$ & SD & Score \\
\hline 1. & $\begin{array}{l}\text { Graphic organizer helps you } \\
\text { clarify information from the } \\
\text { passage. }\end{array}$ & 11 & 16 & & & & 119 \\
\hline 2 & $\begin{array}{l}\text { Graphic organizer assists you } \\
\text { to show relationship of the } \\
\text { passage. }\end{array}$ & 21 & 6 & & & & 129 \\
\hline 3. & $\begin{array}{l}\text { Graphic organizer assists you } \\
\text { to organize the passage into } \\
\text { main idea, supporting details, } \\
\text { concluding, etc. }\end{array}$ & 8 & 18 & 1 & & & 115 \\
\hline 4. & $\begin{array}{l}\text { Graphic organizer organizes } \\
\text { some information into a } \\
\text { paragraph. }\end{array}$ & 22 & 2 & 3 & & & 124 \\
\hline 5. & $\begin{array}{l}\text { Graphic organizer helps you } \\
\text { understand the context of the } \\
\text { passage. }\end{array}$ & 7 & 19 & 1 & & & 114 \\
\hline 6. & $\begin{array}{l}\text { Graphic organizer assists you } \\
\text { to link the new material with } \\
\text { your prior knowledge. }\end{array}$ & 3 & 19 & 5 & & & 106 \\
\hline 7. & $\begin{array}{l}\text { Graphic organizer provides } \\
\text { foundation for understanding } \\
\text { information from the passage. }\end{array}$ & 1 & 25 & 1 & & & 108 \\
\hline 8. & $\begin{array}{l}\text { Graphic organizer helps you } \\
\text { arrange the information } \\
\text { systematically. }\end{array}$ & 15 & 11 & 1 & & & 122 \\
\hline 9. & $\begin{array}{l}\text { Graphic organizer is effective } \\
\text { to use in learning extensive }\end{array}$ & 5 & 22 & & & & 113 \\
\hline
\end{tabular}


Graphic Organizer as Strategy to Teach Extensive Reading

\begin{tabular}{|c|c|c|c|c|c|}
\hline & reading. & & & & \\
\hline 10. & $\begin{array}{l}\text { Graphic organizer guides you } \\
\text { to summarize well. }\end{array}$ & 7 & 19 & 1 & 114 \\
\hline \multicolumn{5}{|c|}{$\begin{array}{ll}\text { Total Score } \\
\end{array}$} & 1164 \\
\hline
\end{tabular}

The detail result of attitude scale distributed to the students is explained as follows: (1) for the statement "Graphic organizer helps you clarify information from the passage', the score $=119 / 27=4.4$; it shows that the respondents agree with the statement, (2) for the statement "Graphic organizer assists you to show relationship of the passage", the score is = $129 / 27=4.77$; it shows that the respondents strongly agree with the statement because the score is nearer to 5; (3) for the statement "Graphic organizer assists you to organize the passage into main idea, supporting details, concluding, etc", the score $=115 / 27=4.26$; it indicates that the respondents agree with the statement; (4) for the statement "Graphic organizer organizes some information into a paragraph", the score $=124 / 27=4.59$; it shows that the respondents strongly agree with the statement; (5) for the statement "Graphic organizer helps you understand the context of the passage", the score is $=114 / 27=4.22$; it can be concluded that the respondents agree with the statement; (6) for the statement "Graphic organizer assists you to link the new material with your prior knowledge", the score is $=106 / 27=3.92$; it shows that the respondents agree with the statement; (7) for the statement "Graphic organizer provides foundation for understanding information from the passage:, the score is $=108 / 27=4$; it can be concluded that the respondents agree with the statement; (8) for the statement "Graphic organizer helps you arrange the information systematically", the score is $=122 / 27=4.51$; it indicates that the respondents agree with the statement; (9) for the statement "Graphic organizer is effective to use in learning extensive reading", the score is $=113 / 27=4.18$; it shows that the respondents agree with the statement; and (10) for the statement "Graphic organizer guides you to summarize well", the score is $=114 / 27=4.22$; it indicates that the respondents agree with the statement. From the whole of the attitude scale result, it can be concluded that the utilization of graphic organizer gains good response from the students.

\section{DISCUSSION}

The findings of the research highlight several points. First, based on the observation done by the observer, the researcher and the students applied the use of graphic organizer well in reading class. It is proven by the observation checklist result. All activities were done by the researcher and the students suitable with the steps planned in applying the graphic organizer. The researcher assisted and guided the students during the graphic organizer applied. The researcher was assisted by her partner to observe if all activities were done well. She used observation checklists to guide her. The observation checklists were designed and prepared during the application of graphic organizer with different passage. It was because different type of passage used different graphic organizer.

Secondly, the result of the students' summarization based on graphic organizer created was categorized into good. Their graphic organizer assisted and guided them to make a summary of different passage distributed by the researcher. They were able to summarize covering four aspects; Thesis Statement, Content Inclusion \& Exclusion, Sentence 


\section{Astried Damayanti}

Transformation, Grammar and Mechanics. The students summarized three passage from different type of non-fiction, namely chronological order, compare and contrast and description passage. The mean of the whole students' work is 81.67. The result shows that the students' reading comprehension is good. They summarized well based on the graphic organizer created in the previous activity. It indicates that graphic organizer assisted them to understant the content of the passage and classify the important information to be summarized. In short, graphic organizer helps, assists and guides the students to understand the passage distributed well and makes the passage easier to be summarized.

Thirdly, the result of students' attitude scale shows that the students gave good response toward the application of graphic organizer in Extensive Reading on Non-fiction class. From ten favorable statements provided, the students answered strongly agree for two statements and agree for eight statements.

The findings of the research are similar to several relevant studies. Manoli and Papadopoulou (2012) conducted research about graphic organizers as one of reading strategies. The result shows that graphic organizer was effective to be utilized in learning reading. Meanwhile, Heidarifard (2014) also carried out experimental research about the effect of graphic organizer on learning reading. The findings of the research indicated that graphic organizer contributed in learning reading. Besides, the utilization of graphic organizer also gained postive response from the learners. Research about graphic organizer was also conducted by Sam and Rajan (2013). They aimed to develop the reading comprehension of ESL students. The result of the research shows that the students' creativity was motivated to comprehend the passage delivered after using graphic organizer.

Similarly, the findings of the research are also in line with some previous theories. Greenall and Pye (1991) classify the three factors to stimulate the learner's motivation; they are the text, the task and the teacher's role. The utilization of graphic organizer accommodates those three factors. Interesting text or passage stimulates the students' motivation. In the research, the researcher distributed passage with familiar topic, idea and information to promote their motivation. She also facilitated the learning with interesting task or activity. Creating graphic organizer was the new activity for the students. By applying the new activity, the students' motivation is created and artificially maintained. Meanwhile, the researcher as the teacher facilitated learning by applying graphic organizer to promote motivation. Further, Olszak (2014) argues that strategy of language learning becomes one of the basic aspects in reading comprehension development. Appropriate strategy assists the learners to progress their reading ability. Graphic organizer as the new strategy guides the students to gain information of the passage. It helped them arrange the information systematically. Consequently, they were able to summarize well with the information arranged in their graphic organizer. Further, Sam and Rajan (2013) also explain that graphic organizers as tool for teachers to assist students to reach higher achievement in their skill of reading comprehension. The students can focus on the content well and classify it into several understandable units. In conclusion, graphic organizer strategy is effective to enhance reading comprehension. 


\section{CONCLUSION}

The result of the research shows that students' summarization of the passage after the application of graphic organizer is good. It indicates that the use graphic organizer contributes to assist students' comprehension in passage. Meanwhile, the students gave good response toward the utilization of graphic organizer in extensive reading learning. It is shown from the result of attitude scale distributed to the students. The application of graphic organizer is conducted with the following steps: (1) providing the passage; (2) assigning the students to read the passage carefully; (3) explaining the appropriate graphic organizer for the passage; (4) instructing the students to create graphic organizer suitable with the passage; (5) asking the students to make a summary from the graphic organizer made. Based on the observation done by the observer, the result shows that the graphic organizer was applied well by the researcher. It can be seen from the observation checklist result.

Some suggestions are recommended for the reading learners, the teacher and the next researcher. The reading learners can apply graphic organizer to assist them comprehend the text or passage. Graphic organizer helps and guides them to gain important information. Besides, it will lead them to arrange the information systematically to be a good summary. The teacher can use graphic organizer as strategy in reading class. It will be different way to teach reading with appropriate graphic organizer. Further, the next researcher is suggested to conduct the same research with different types of passage and graphic organizer. It will enrich and enlarge knowledge about graphic organizer in learning reading.

\section{REFERENCES}

Aliponga, J. (2013). Reading Journal: Its Benefits for Extensive Reading. International Journal of Humanities and Social Science, 3(12), 73-80.

Ary, D et al. (2002). Introduction to Research in Education. Stamford: Thomas Learning, Inc.

Basuki, Y., Damayanti, A., \& Dewi, S.U. (2018). Analyzing EFL Learners' Needs for Vocabulary Learning Materials. Journal LinguA-LiterA 1 (2), 65-74

Basuki, Y., Damayanti, A., \& Dewi, S,U. 2018. Vocabulary Coursebook for EFL Learners of Higher Education in Indonesia. International Journal of Education \& Literacy Studies, 6 (4), 122-128

Bearne, E. (2002). Making progress in writing. UK: RoutledgeFalmer

Brown, D. H. (2007). Teaching by Principles. New York: Pearson Education, Inc.

Chiu, C. (2015). Enhancing Reading Comprehension and Summarization Abilities of EFL Learners Through Online Summarization Practice. The Journal of Language Teaching and Learning, 1,79-95

Damayanti, A. (2018). Authentic Materials For Teaching Reading. Journal LinguA-LiterA 1 (1) $11-20$

Greenall, S. \& Pye, D. (1991). Reading 4. Cambridge: University Press

Harmer, J. (2007). How to Teach English. England: Pearson Education Limited

Heidarifard, M. (2014). The Effect of Graphic Organizers on L2 Learners' Reading Comprehension. Journal of American Science, 10(3s), 62-72 


\section{Astried Damayanti}

Manoli, P. \& Papadopoulou, M. (2012). Graphic Organizers as a Reading Strategy: Research Findings and Issues. Creative Education, 3 (3), 348-356

Mar, R.A., Oatley, K., Hirsh, J., Paz, J. D., \& Peterson, J. B. (2006). Bookworms versus nerds: Exposure to fiction versus non-fiction, divergent associations with social ability, and the simulation of fictional social worlds. Journal of Research in Personality 40, 694-712

McNeil, J.D. (1992). Reading Comprehension: New Directions for Classroom Practice. New York: HarperCollins Publishers

Olszak, I. (2014). Graphic and semantic organizers as cognitive strategies in reading instruction. A Journal of English Studies 6 (3), 28-41

Rajan, P. \& Sam D, P. (2013). Using Graphic Organizers to Improve Reading Comprehension Skills for the Middle School ESL Students. English Language Teaching, 6 (2), 155- 170

Robb, A. (2003). 40 Graphic Organizers that Build Comprehension During Independent Reading. USA: Scholastic Inc.

Tiryaki, M.Z. \& Tutunis, B. (2012). The Role of Extensive Reading on Vocabulary Development. International Association of Research in Foreign Language Education and Applied Linguistics ELT Research Journal, 1(4), 209-215

Wray, D. \& Lewis, M. (1997). Children reading and writing nonfiction. London, UK: RoutledgeFalmer.

Yulia, M. F. (2018). Extensive Reading For Indonesian University Students: An Alternative Framework For Implementation. LLT Journal: A Journal on Language and Language Teaching. 21(2), 207 - 2018 